\title{
Bleeding prevalence in COVID-19 patients receiving intensive antithrombotic prophylaxis
}

\author{
Chiara Kessler $^{1} \cdot$ Hans Stricker ${ }^{2} \cdot$ Daniela Demundo $^{3} \cdot$ Luigia Elzi $^{4} \cdot$ Rita Monotti $^{5} \cdot$ Giorgia Bianchi $^{6}$. \\ Michael Llamas ${ }^{7} \cdot$ Luca Spinedi $^{2}$. Davide Rossi ${ }^{1}$ - Alessandro Felice Chiesa ${ }^{7}$. Alberto Pagnamenta ${ }^{7} \cdot$ Marco Conti $^{7}$. \\ Gabriele Casso $^{8}$. Elisa Stoira ${ }^{5}$. Elisa Valenti ${ }^{7}$. Giuseppe Colucci ${ }^{9}$. Georg Stussi ${ }^{1}$ - Bernhard Gerber ${ }^{1}$ (1) . \\ Marco Previsdomini ${ }^{7}$
}

Published online: 14 August 2020

(c) Springer Science+Business Media, LLC, part of Springer Nature 2020

\section{To the editor}

In-hospital patients with severe acute respiratory syndrome coronavirus 2-induced disease (COVID-19) have a high risk of thrombosis [1-4]. Pharmacological thromboprophylaxis is strongly encouraged, and several experts even suggest the use of high-dose prophylaxis or full anticoagulation for patients with severe disease at low risk of bleeding, but up to now, data on safety of this approach are lacking $[1,5-8]$.

Here, we report observational single-center prevalence of major bleeding events (ISTH definition, Table S1) in patients with COVID-19 receiving intensive thromboprophylaxis [9]. We included all consecutive adult patients with laboratoryproven COVID-19 treated between April 1st and May 6th 2020 at the Hospital La Carità, Locarno, Switzerland. On April 1st 2020, we have implemented the following intensive

Bernhard Gerber and Marco Previsdomini contributed equally and are listed alphabetically.

Electronic supplementary material The online version of this article (https://doi.org/10.1007/s11239-020-02244-y) contains supplementary material, which is available to authorized users.

Bernhard Gerber

bernhard.gerber@eoc.ch

1 Clinic of Hematology, Oncology Institute of Southern Switzerland, 6500 Bellinzona, Switzerland

2 Department of Angiology, Ospedale La Carità, Locarno, Switzerland

3 Istituto Imaging Svizzera Italiana, Ente Ospedaliero Cantonale, Locarno, Switzerland

4 Division of Infectious Diseases, Ospedale San Giovanni, Ente Ospedaliero Cantonale, Bellinzona, Switzerland

5 Department of Internal Medicine, Ospedale La Carità, Locarno, Switzerland thromboprophylaxis scheme: Patients with COVID-19 with an estimated glomerular filtration rate (eGFR) $\geq 30 \mathrm{ml} /$ $\min / 1.73 \mathrm{~m}^{2}$ received subcutaneous enoxaparin twice daily (BID) at a dose of $40 \mathrm{mg}(<80 \mathrm{~kg})$, or $60 \mathrm{mg}(\geq 80 \mathrm{~kg})$ for a minimum of 14 days (dose level 1). Dose escalation to $60 \mathrm{mg}$ BID $(<80 \mathrm{~kg}$ ), or $80 \mathrm{mg}$ BID $(\geq 80 \mathrm{~kg}$ ) was discussed if D-dimer levels increased during follow-up $>$ $2.0 \mathrm{mg} / \mathrm{L}$, irrespective of the presence of thromboembolic complications (dose level 2). Patients with COVID-19 with an eGFR $<30 \mathrm{ml} / \mathrm{min} / 1.73 \mathrm{~m}^{2}$ received subcutaneous UFH at a dose of 5000 IU three times a day in the regular ward, or continuous intravenous UFH in the intensive care unit (ICU) with a target anti-Xa activity of $0.3-0.5 \mathrm{U} / \mathrm{ml}$. The study was approved by the Ethical Committee Ticino, Switzerland (2020-00838 RIF.CE 3621).

A total of 270 inpatients with confirmed COVID-19 were eligible for this analysis. $22(8.2 \%)$ patients received regular thromboprophylaxis with once daily enoxaparin $40 \mathrm{mg}$ or UFH 5000 IU two times a day, $183(67.8 \%)$ patients received the intensified thromboprophylaxis, and $65(24 \%)$ patients had full anticoagulation (Table 1). Of the 65 patients with therapeutic anticoagulation, 20

6 Department of Nephrology, Ospedale La Carità, Locarno, Switzerland

7 Department of Intensive Care Medicine of the Ente Ospedaliero Cantonale (EOC), Intensive Care Units of Regional Hospital of Bellinzona, Locarno, Lugano and Mendrisio, Locarno, Switzerland

8 Department of Cardiothoracic Anesthesiology and Intensive Care, Cardiocentro Ticino, Lugano, Switzerland

9 Service of Hematology, Clinica Luganese Moncucco, Lugano, Switzerland 
Table 1 Characteristics of patients with COVID-19 with and without major bleedings

\begin{tabular}{|c|c|c|c|}
\hline & $\begin{array}{l}\text { COVID-19 patients without } \\
\text { major bleedings } \\
\mathrm{n}=256(94.8 \%)\end{array}$ & $\begin{array}{l}\text { COVID-19 patients with major } \\
\text { bleedings } \\
\mathrm{n}=14(5.2 \%)\end{array}$ & $p$-value \\
\hline Age (years) ${ }^{\mathrm{a}}$ & $70.28(22-96)$ & $73.89(59-88)$ & 0.17 \\
\hline Male sex $(\%)$ & $157(61.3)$ & $9(64.3)$ & 0.83 \\
\hline Time from first symptoms to hospital admission (days) ${ }^{\mathrm{a}}$ & $6(0-43)$ & $6.5(0-18)$ & 0.62 \\
\hline Comorbidities (\%) & $194(75.8)$ & $14(100)$ & 0.04 \\
\hline Cardiovascular disease $(\%)$ & $102(39.8)$ & $7(50)$ & \\
\hline Diabetes mellitus (\%) & $55(21)$ & $4(28.6)$ & \\
\hline Arterial hypertension (\%) & $128(50)$ & $9(64.3)$ & \\
\hline Pulmonary disease $(\%)$ & $55(21.5)$ & $5(35.7)$ & \\
\hline Chronic renal failure $(\%)$ & $31(12.6)$ & $2(14.3)$ & \\
\hline Malignancy (\%) & $18(7.1)$ & $1(7.1)$ & \\
\hline Immunosuppression (\%) & $21(8.2)$ & $2(14.3)$ & \\
\hline COVID-19 clinical syndrome (\%), WHO definition [15] & & & 0.093 \\
\hline Mild illness & $13(5.1)$ & $0 .(0)$ & \\
\hline Pneumonia & $27(10.5)$ & $0(0)$ & \\
\hline Severe Pneumonia & $114(44.5)$ & $4(28.6)$ & \\
\hline Mild ARDS & $13(5.1)$ & $1(7.1)$ & \\
\hline Moderate ARDS & $21(8.2)$ & $4(28.6)$ & \\
\hline Severe ARDS ${ }^{b}$ & $68(26.6)$ & $5(35.7)$ & \\
\hline \multicolumn{4}{|l|}{ COVID therapy protocol $(\%)$} \\
\hline Hydroxychloroquine & $56(21.9)$ & $6(42.9)$ & 0.1 \\
\hline Lopinavir + ritonavir & $40(15.6)$ & $6(42.9)$ & 0.02 \\
\hline Remdesivir & $26(10.2)$ & $2(14.6)$ & 0.65 \\
\hline Antithrombotic drug $(\%)$ & & & 0.26 \\
\hline UFH & $39(15.3)$ & $5(35.7)$ & \\
\hline LMWH & $201(78.5)$ & $9(64.3)$ & \\
\hline DOAC & $8(3.1)$ & 0 & \\
\hline VKA & $8(3.1)$ & 0 & \\
\hline Antithrombotic strategy $^{c}$ & & & $<0.01$ \\
\hline Regular prophylaxis & $22(8.6)$ & 0 & \\
\hline Intensive prophylaxis (dose level 1) & $151(59)$ & $2(14.3)$ & \\
\hline Intensive prophylaxis (dose level 2) & $29(11.3)$ & $1(7.1)$ & \\
\hline Full anticoagulation & $54(21.1)$ & $11(78.6)$ & \\
\hline $\begin{array}{l}\text { Dose intensification of the antithrombotic strategy during inpa- } \\
\text { tient treatment }(\%)\end{array}$ & $65(25.4)$ & $8(57.1)$ & 0.03 \\
\hline ICU treatment $(\%)$ & $65(26.9)$ & $11(78.6)$ & $<0.01$ \\
\hline Mortality (\%) & $40(15.6)$ & $6(42.9)$ & 0.02 \\
\hline
\end{tabular}

WHO World Health Organization, ARDS acute respiratory distress syndrome, UFH unfractionated heparin, $L M W H$ low molecular weight heparin, $D O A C$ direct oral anticoagulant, $V K A$ vitamin $\mathrm{K}$ antagonist, $O D$ once daily, $B I D$ two times per day, $T I D$ three times per day, $I N R$ international normalized ratio, anti-Xa anti-activated coagulation factor $\mathrm{X}$ activity, ICU intensive care unit

*Groups were compared by $\mathrm{Chi}^{2}$, Fisher's exact test or ANOVA, as appropriate

aedian (range)

${ }^{\mathrm{b}}$ Severe ARDS includes deaths attributed to not otherwise specified ARDS

${ }^{\mathrm{c}}$ Regular prophylaxis = enoxaparin $40 \mathrm{mg}$ OD or subcutaneous UFH 5000 UI BID if eGFR $<30 \mathrm{ml} / \mathrm{min} / 1.73 \mathrm{~m}^{2}$, Intensive prophylaxis (dose level 1) = subcutaneous enoxaparin $40 \mathrm{mg}$ BID $(<80 \mathrm{~kg})$, or $60 \mathrm{mg} \mathrm{BID}(\geq 80 \mathrm{~kg})$, if eGFR $<30 \mathrm{ml} / \mathrm{min} / 1.73 \mathrm{~m}^{2}$ subcutaneous UFH $5000 \mathrm{IU}$ TID in the regular ward, and continuous intravenous UFH in the ICU (target anti-Xa $\leq 0.4 \mathrm{U} / \mathrm{ml}$ ), Intensive prophylaxis (dose level 2$)=$ subcutaneous enoxaparin $60 \mathrm{mg}$ BID $(<80 \mathrm{~kg})$, or $80 \mathrm{mg}$ BID $(\geq 80 \mathrm{~kg})$, if eGFR $<30 \mathrm{ml} / \mathrm{min} / 1.73 \mathrm{~m}^{2}$ continuous intravenous UFH (target anti-Xa $0.3-0.5 \mathrm{U} / \mathrm{ml}$ ), Full anticoagulation = weight adapted enoxaparin, continuous intravenous UFH (anti-Xa 0.3-0.7 U/ml), standard dose DOAC, or VKA with a target INR of $2.5( \pm 0.5)$ 
(30.7\%) patients had prior anticoagulation for atrial fibrillation (Afib) $(n=17,26.2 \%)$ and for venous thromboembolism (VTE) $(\mathrm{n}=3,4.6 \%)$ unrelated to COVID-19. During follow-up, 73 (27\%) patients underwent dose escalation from regular prophylaxis or dose level 1 to dose level 2, or to full anticoagulation. Reasons for dose escalation were increasing D-dimer levels $(\mathrm{n}=31,11.5 \%)$, acute VTE $(n=36,13.3 \%)$, and newly diagnosed Afib $(n=6,2.2 \%)$.

Four $(2.2 \%)$ bleedings, all retroperitoneal, were observed in the 183 patients receiving intensified prophylaxis (Table S2). Three out of these four patients had concomitant anti-platelet therapy. $10(16.6 \%)$ bleedings occurred in patients receiving full anticoagulation because of Afib, catheter-associated thrombosis or pulmonary embolism (Table S2). No patient had overt disseminated intravascular coagulation or heparin-induced thrombocytopenia. Fatal bleeding occurred in none of the 183 patients receiving intensive thromboprophylaxis, and in three (4.6\%) of the 65 patients with full anticoagulation.

The observed bleeding prevalence in patients with COVID-19 receiving high-dose thromboprophylaxis is two-fold higher when compared to medically ill patients receiving standard dose thromboprophylaxis, but lower than the 5.5\% major bleeding rate in critically ill medical patients receiving standard dose thromboprophylaxis [10, 11]. Patients with COVID-19 who receive full-dose anticoagulation are at higher risk of major bleeding. Preventing the need for therapeutic anticoagulation is therefore a major goal of thromboprophylaxis. The predominance of intramuscular hemorrhage with two thirds of the bleedings localized in the retroperitoneum, the gluteal and the thigh muscles warrants further investigation (Table S2). SARSCoV-2 induced muscle necrosis, and vasculopathy might contribute to this bleeding phenotype [12-14].

In conclusion, our data are reassuring and supportive of intensive thromboprophylaxis for hospitalized patients with COVID-19. Most major bleedings occurred after two weeks of hospitalization, and dose de-escalation after the first 10 to 14 days might be considered in patients with a favorable clinical course. Prospective trials are required to optimize patient selection, dosing and treatment duration for patients with COVID-19.

Acknowledgements The authors thank all colleagues and staff members involved in the care of patients with COVID-19 in the hospital La Carità, Locarno.

Authors contribution BG, CK, MP, and HS designed the study; CK, $\mathrm{MP}$, and BG collected and analyzed the data; GS performed the statistical analysis; CK, BG, and MP wrote the first draft of the manuscript; all authors collected patient data, and critically read, discussed and corrected the manuscript.
Funding No funding source involved.

Data availability Original data can be requested by contacting the corresponding author.

\section{Compliance with ethical standards}

Conflict of interest D. Rossi reports grants and personal fees from Abbvie, grants and personal fees from Janssen, grants and personal fees from Gilead, grants and personal fees from AstraZeneca, personal fees from Verastem, personal fees from Loxo, grants from Cellestia, during the conduct of the study; B. Gerber reports grants and personal fees from Pfizer; personal fees and funding for accredited continuing medical education from Sanofi and Alnylam, during the conduct of the study, funding for accredited continuing medical education program from Axonlab, Bayer, Bristol Myers Squibb, Daiichi-Sankyo, Janssen, Mitsubishi Tanabe Pharma, NovoNordisk, Octapharma, Takeda, Sanofi, SOBI; non-financial support from Axonlab and Thermo Fisher from outside the submitted work; All other authors report no conflict of interest related to this study.

Ethical approval The study was approved by the Ethical Committee Ticino, Switzerland (2020-00838 RIF.CE 3621).

\section{References}

1. Connors JM, Levy JH (2020) COVID-19 and its implications for thrombosis and anticoagulation. Blood. https://doi.org/10.1182/ blood.2020006000

2. Levi M, Thachil J, Iba T, Levy JH (2020) Coagulation abnormalities and thrombosis in patients with COVID-19. Lancet Haematol 7(6):e438-e440. https://doi.org/10.1016/S2352-3026(20)30145-9

3. Cui S, Chen S, Li X, Liu S, Wang F (2020) Prevalence of venous thromboembolism in patients with severe novel coronavirus pneumonia. J Thromb Haemost 18(6):1421-1424. https://doi. org/10.1111/jth. 14830

4. Middeldorp S, Coppens M, van Haaps TF, Foppen M, Vlaar AP, Muller MCA, Bouman CCS, Beenen LFM, Kootte RS, Heijmans J, Smits LP, Bonta PI, van Es N (2020) Incidence of venous thromboembolism in hospitalized patients with COVID-19. J Thromb Haemost. https://doi.org/10.1111/jth.14888

5. Bikdeli B, Madhavan MV, Jimenez D, Chuich T, Dreyfus I, Driggin E, Nigoghossian C, Ageno W, Madjid M, Guo Y, Tang LV, Hu Y, Giri J, Cushman M, Quere I, Dimakakos EP, Gibson CM, Lippi G, Favaloro EJ, Fareed J, Caprini JA, Tafur AJ, Burton JR, Francese DP, Wang EY, Falanga A, McLintock C, Hunt BJ, Spyropoulos AC, Barnes GD, Eikelboom JW, Weinberg I, Schulman S, Carrier M, Piazza G, Beckman JA, Steg PG, Stone GW, Rosenkranz S, Goldhaber SZ, Parikh SA, Monreal M, Krumholz HM, Konstantinides SV, Weitz JI, Lip GYH (2020) COVID-19 and thrombotic or thromboembolic disease: implications for prevention, antithrombotic therapy, and follow-up. J Am Coll Cardiol. https://doi.org/10.1016/j.jacc.2020.04.031

6. Tang N, Bai H, Chen X, Gong J, Li D, Sun Z (2020) Anticoagulant treatment is associated with decreased mortality in severe coronavirus disease 2019 patients with coagulopathy. J Thromb Haemost 18(5):1094-1099. https://doi.org/10.1111/jth.14817

7. Klok FA, Kruip M, van der Meer NJM, Arbous MS, Gommers D, Kant KM, Kaptein FHJ, van Paassen J, Stals MAM, Huisman MV, Endeman H (2020) Incidence of thrombotic complications in critically ill ICU patients with COVID-19. Thromb Res. https ://doi.org/10.1016/j.thromres.2020.04.013 
8. Llitjos JF, Leclerc M, Chochois C, Monsallier JM, Ramakers M, Auvray M, Merouani K (2020) High incidence of venous thromboembolic events in anticoagulated severe COVID-19 patients. J Thromb Haemost. https://doi.org/10.1111/jth.14869

9. Schulman S, Kearon C, Subcommittee on Control of Anticoagulation of the Scientific and Standardization Committee of the International Society on Thrombosis and Haemostasis (2005) Definition of major bleeding in clinical investigations of antihemostatic medicinal products in non-surgical patients. $\mathbf{J}$ Thromb Haemost 3(4):692-694. https://doi.org/10.1111/j.1538-7836.2005.01204.x

10. Kearon C, Akl EA, Comerota AJ, Prandoni P, Bounameaux H, Goldhaber SZ, Nelson ME, Wells PS, Gould MK, Dentali F, Crowther M, Kahn SR (2012) Antithrombotic therapy for VTE disease: antithrombotic therapy and prevention of thrombosis, 9th ed: American College of Chest Physicians Evidence-Based Clinical Practice Guidelines. Chest 141(2 Suppl):e419S-e496S. https ://doi.org/10.1378/chest.11-2301

11. PROTECT Investigators for the Canadian Critical Care Trials Group and the Australian and NewZealand Intensive Care Society Clinical Trials Group, Cook D, Meade M, Guyatt G, Walter S, Heels-Ansdell D, Warkentin TE, Zytaruk N, Crowther M, Geerts W, Cooper DJ, Vallance S, Qushmaq I, Rocha M, Berwanger O, Vlahakis NE (2011) Dalteparin versus unfractionated heparin in critically ill patients. N Engl J Med 364(14):1305-1314. https:// doi.org/10.1056/NEJMoa1014475

12. Wichmann D, Sperhake JP, Lutgehetmann M, Steurer S, Edler C, Heinemann A, Heinrich F, Mushumba H, Kniep I, Schroder AS,
Burdelski C, de Heer G, Nierhaus A, Frings D, Pfefferle S, Becker $\mathrm{H}$, Bredereke-Wiedling H, de Weerth A, Paschen HR, Sheikhzadeh-Eggers S, Stang A, Schmiedel S, Bokemeyer C, Addo MM, Aepfelbacher M, Puschel K, Kluge S (2020) Autopsy findings and venous thromboembolism in patients with COVID-19. Ann Intern Med. https://doi.org/10.7326/M20-2003

13. Varga Z, Flammer AJ, Steiger P, Haberecker M, Andermatt R, Zinkernagel AS, Mehra MR, Schuepbach RA, Ruschitzka F, Moch $\mathrm{H}$ (2020) Endothelial cell infection and endotheliitis in COVID19. Lancet 395(10234):1417-1418. https://doi.org/10.1016/S0140 $-6736(20) 30937-5$

14. Ackermann M, Verleden SE, Kuehnel M, Haverich A, Welte T, Laenger F, Vanstapel A, Werlein C, Stark H, Tzankov A, Li WW, Li VW, Mentzer SJ, Jonigk D (2020) Pulmonary vascular endothelialitis, thrombosis, and angiogenesis in Covid-19. N Engl J Med. https://doi.org/10.1056/NEJMoa2015432

15. World Health Organization (2020). Clinical Management of COVID-10 - Interim guidance, 27 May 2020 WHO, Geneva. Report available at https://apps.who.int/iris/handle/10665/33219 6. Accessed 16 June 2020

Publisher's Note Springer Nature remains neutral with regard to jurisdictional claims in published maps and institutional affiliations. 